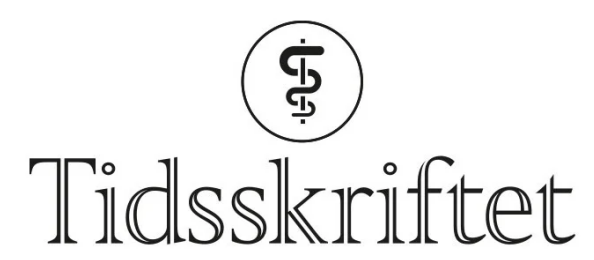

DEN NORSKE LEGEFORENING

\title{
Forkortelser skaper avstand
}

\author{
FRA REDAKTØREN
}

\section{PETTER GJERSVIK}

petter.gjersvik@medisin.uio.no

Petter Gjersvik er medisinsk redaktør i Tidsskriftet og professor ved Institutt for klinisk medisin, Universitetet i Oslo.

\section{Hvis du ønsker å nå frem til lesere utenfor eget fagmiljø, bør du være varsom med bruk av forkortelser.}

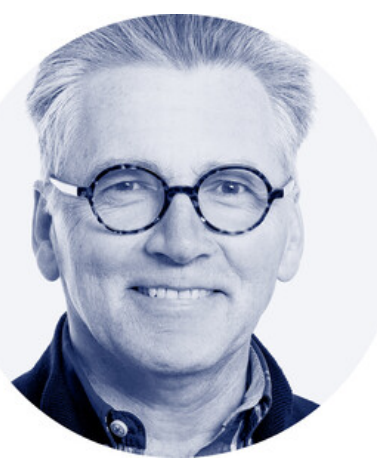

Foto: Sturlason

Mange faguttrykk er lange. Når slike uttrykk gjentas ofte i en tekst, kan det være fristende for forfatteren å bruke forkortelser. I mange tilfeller vil slike forkortelser fremme tekstflyten og lette lesingen. Men ofte vil de snarere hemme tekstflyten, vanskeliggjøre forståelsen av innholdet og hindre at budskapet når frem. Forkortelser styrker identitet og samhold hos dem som vet hva forkortelsen betyr, men virker ofte ekskluderende på andre (1). Forkortelser skaper avstand.

De fleste forkortelser i medisin er basert på de første bokstavene i ord, slik som MS for multippel sklerose og FSH for follikkelstimulerende hormon. Mange er basert på engelskspråklige faguttrykk, slik som NSAID for non-steroid anti-inflammatory drug og CNS for central nervous system. Det er enkelt å ta dem i bruk, og de fleste leger vet hva de står for. Men noen forkortelser kan ha ulik betydning for leger i ulike fag; CSF kan leses både som cerebrospinalvæske, kolonistimulerende faktor og cytostatisk faktor.

Meningene om forkortelser kan være delte, særlig når faguttrykket og/eller forkortelsen er vanskelig å lese, slik som facioscapulohumoral muskeldystrofi (FSHMD) og akutt hjerteinfarkt uten ST-hevelse (NSTEMI). Nye metoder i klinisk medisin som non-invasiv prenatal test, sublingval immunterapi og kontrollert donasjon etter sirkulasjonsstans kan omtales som hhv. NIPT, SLIT og cDCD, men det fremmer verken lesingen eller forståelsen 
for de fleste av oss. Få lesere vil vite hva MIS-C står for (svar: multiorgan inflammatory syndrome in children). I mitt eget fag, dermatologi, snakker hudleger om $\mathrm{AD}$ (dvs. atopisk dermatitt) og EB (dvs. epidermolysis bullosa), men vi bør helst ikke gjøre det når vi kommuniserer med andre grupper.

Noen forkortelser kan se godt ut og klinge godt, slik som HIT, som står for heparinindusert trombocytopeni. Da man oppdaget en liknende form for trombocytopeni uten forutgående bruk av heparin, kalte man det aHIT (2) . Slik kan forkortelser mer forvirre enn klargjøre.

\section{«Forkortelser styrker identitet og samhold hos dem som vet hva forkortelsen betyr, men virker ofte ekskluderende på andre»}

Tidsskriftet har en restriktiv praksis for bruk av forkortelser (3). Begrunnelsen er at vi $\emptyset n s k e r$ å nå frem til flest mulig lesere, også dem som ikke er fortrolig med den aktuelle forkortelsen. Enkelte forkortelser er så velkjente og etablerte at de uten videre aksepteres, slik som DNA, WHO, aids og kols. Disse fremgår av Tidsskriftets ordliste (3). Nye forkortelser blir lagt til listen når de vurderes som kurante, slik det ble gjort med CT, MR og ADHD for flere år siden. Forkortelser som ikke står på listen, bør stort sett unngås.

De fleste forfattere er takknemlig for å få veiledning fra redaksjonen om å unngå forkortelser og hvordan det kan gjøres i praksis (3). Noen vil likevel forsvare sin bruk av forkortelser, og deres argumenter faller ofte i tre kategorier, som jeg vil kommentere her:

«Alle i fagmiljøet kjenner forkortelsen.» Poenget er at mange forkortelser ikke er kjent utenfor fagmiljøet. Når man skriver, er det jo gjerne for å nå frem med et budskap også til lesere utenfor eget fagmiljø.

«Forkortelsen blir forklart første gang den brukes.» Problemet er at få lesere leser en artikkel fra start til mål. De som begynner å lese lenger ut eller stadig hopper fremover i teksten, vil lett miste eller glemme forklaringen og dermed miste motivasjon for å lese videre.

«Å skrive det fulle faguttrykket helt ut hver gang vil gjøre teksten vanskelig å lese.» Men det er ikke snakk om å erstatte forkortelsen med det fulle faguttrykket hver gang. Avhengig av hva det dreier seg om, kan man skrive sykdommen, slik behandling, denne metoden eller liknende, stryke eller skrive litt om. En annen løsning kan være å bruke forkortelsen sammen med et lett gjenkjennelig ord, slik som ALS-pasienter, HSV-profylakse og NIPT-test (3). Dette kan være en god løsning også ved omtale av kompliserte molekylære strukturer med lange navn, slik som ACE2-protein og AMPA-reseptor. Det samme gjelder terapeutiske prosedyrer, f.eks. PCI-behandling, og kliniske studier, som ALERT-studien og 4 S-studien. Med en pragmatisk tilnærming finnes det alltid en løsning.

En psykologvenn av meg jobber med barn med psykisk utviklingshemning, der man bruker ulike teknikker for å takle uheldig atferd. Mange av disse metodene omtales med trebokstavsforkortelser. En teknikk han ikke lærte om i psykologistudiet, kaller han på spøk for MMS-metoden. Forkortelsen står for minst mulig styr. Hvilket uttrykk formidler budskapet best?

Tekster med forkortelser kan være vanskelig å lese. Skriv heller slik at budskapet når frem til flest mulig av dem du ønsker å nå (44,5). Unngå forkortelser der du kan.

\section{LITTERATUR}

1. Hales AH, Williams KD, Rector J. Alienating the audience: How abbreviations hamper scientific communication. Psychological Science Observer 2017; 30: 22-4.

2. Lægreid IJ, Sørvoll IH, Ernstsen SL et al. Nyoppdaget katastrofal antistoffdannelse etter AstraZeneca-vaksinen. Tidsskr Nor Legeforen 2021; 141. doi: 10.4045/tidsskr.21.0265. [PubMed] 
[CrossRef]

3. Tidsskrift for Den norske legeforening. Forfatterveiledning.

https://tidsskriftet.no/annet/retningslinjer-og-tips-til-forfattere Lest 8.9.2021.

4. Pinker S. The sense of style: The thinking person's guide to writing in the 21st century. New York, NY: Penguin Group, 2014.

5. Nylenna M. Publisere \& presentere. Medisinsk fagformidling i teori og praksis. 2. utg. Oslo: Gyldendal Akademiske, 2015.

Publisert: 27. september 2021. Tidsskr Nor Legeforen. DOI: 10.4045/tidsskr.21.0636

(C) Tidsskrift for Den norske legeforening 2023. Lastet ned fra tidsskriftet.no 26. april 2023. 